\title{
Modulation of miRNAs by Vitamin C in Human Bone Marrow Stromal Cells
}

\author{
Ravindra Kolhe ${ }^{1}$ (D), Ashis K. Mondal ${ }^{1}$, Chetan Pundkar ${ }^{1}$, Sudharsan Periyasamy-Thandavan ${ }^{2}$, \\ Bharati Mendhe ${ }^{2}$, Monte Hunter ${ }^{3}$, Carlos M. Isales ${ }^{3,4}$, William D. Hill ${ }^{2,4}$, Mark W. Hamrick ${ }^{2,4}$ \\ and Sadanand Fulzele $3,4, *$ \\ 1 Department of Pathology, Augusta University, Augusta, GA 30912, USA; rkolhe@augusta.edu (R.K.); \\ amondal@augusta.edu (A.K.M.); cpundkar@augusta.edu (C.P.) \\ 2 Cellular Biology and Anatomy, Augusta University, Augusta, GA 30912, USA; \\ speriyasamy@augusta.edu (S.P.-T.); bmendhe@augusta.edu (B.M.); whill@augusta.edu (W.D.H.); \\ mhamrick@augusta.edu (M.W.H.) \\ 3 Department of Orthopaedic Surgery, Augusta University, Augusta, GA 30912, USA; \\ mohunter@augusta.edu (M.H.); CISALES@augusta.edu (C.M.I.) \\ 4 Institute of Regenerative and Reparative Medicine, Augusta University, Augusta, GA 30912, USA \\ * Correspondence: sfulzele@augusta.edu
}

Received: 22 November 2017; Accepted: 2 February 2018; Published: 8 February 2018

\begin{abstract}
MicroRNAs (miRNAs) are small (18-25 nucleotides), noncoding RNAs that have been identified as potential regulators of bone marrow stromal cell (BMSC) proliferation, differentiation, and musculoskeletal development. Vitamin $C$ is known to play a vital role in such types of biological processes through various different mechanisms by altering mRNA expression. We hypothesized that vitamin $C$ mediates these biological processes partially through miRNA regulation. We performed global miRNA expression analysis on human BMSCs following vitamin C treatment using microarrays containing human precursor and mature miRNA probes. Bioinformatics analyses were performed on differentially expressed miRNAs to identify novel target genes and signaling pathways. Our bioinformatics analysis suggested that the miRNAs may regulate multiple stem cell-specific signaling pathways such as cell adhesion molecules (CAMs), fatty acid biosynthesis and hormone signaling pathways. Furthermore, our analysis predicted novel stem cell proliferation and differentiation gene targets. The findings of the present study demonstrate that vitamin $C$ can have positive effects on BMSCs in part by regulating miRNA expression.
\end{abstract}

Keywords: bone marrow stromal cells; vitamin C; miRNA

\section{Introduction}

Adult stem cell differentiation is a complex process that is heavily influenced by tissue origin and interaction with the cellular microenvironment [1]. Bone marrow stromal cells (BMSCs) are mesenchymal lineage cells that can differentiate into a number of different cell types including osteoblasts, osteocytes, adipocytes, and chondrocytes [2,3]. The differentiation pathway of BMSCs depends in large part on their niche/microenvironment [1]. Targeted gene reprogramming is vital to direct BMSCs toward specific lineages in the field of tissue-engineering. One potential strategy in this regard employs various micronutrient supplements such as amino acids and vitamins to guide BMSC differentiation.

Micronutrients, including vitamin C, are important factors in musculoskeletal development and BMSC biology [4-15]. For example, vitamin $C$ is a key player in collagen synthesis, cell proliferation, and BMSC differentiation [9-15]. Moreover, vitamin $\mathrm{C}$ acts as an antioxidant and prevents oxidative damage of cellular macromolecules. Vitamin $C$ is an essential nutrient that is not synthesized by most 
mammals including humans [16-18] because of a mutation in gulonolactone oxidase (GULO) enzyme. GULO is an important catalyzing enzyme which helps in the conversion of L-gulono-G-lactone into ascorbic acid [17,18]. Human clinical and animal studies have demonstrated that a deficiency of this vitamin leads to musculoskeletal deformities $[19,20]$. Therefore, dietary supplementation of vitamin $C$ is essential for the normal function of BMSCs. Vitamin C stimulates BMSC differentiation by induction of differentiation-specific genes such as Collagen type 1, RUNX2, and ALP [11]. Furthermore, vitamin C is also known to regulate human embryonic stem cell differentiation through epigenetic regulation [21,22].

The role of vitamin $C$ in mesenchymal and embryonic stem cell differentiation has been investigated extensively [21-24]. It is well-established that vitamin $C$ can alter gene expression in embryonic stem cells through epigenetic regulation by directly regulating Tet activity and DNA methylation $[19,20,22,23]$. Epigenetic regulation is a mechanism in which there is change in gene regulation without change in genetic makeup [25]. Epigenetic factors such as DNA methylation and microRNAs are known for their roles in BMSC differentiation and musculoskeletal development [26-31]. Vitamin C and its role in DNA methylation have been well-studied in different biological systems [32-37] but not much is known with regard to miRNA and vitamin C. MicroRNAs are small, non-coding, endogenous, single stranded RNAs comprised of 22 nucleotides that bind to the $3^{\prime}$ untranslated region of target messenger RNA (mRNA) [38,39]. MicroRNA negatively regulates gene expression at the post-transcriptional level by degrading mRNA or by inhibiting translation [38,39]. It has been reported in a number of studies that miRNA regulates almost all cellular events including cell proliferation, differentiation, and development [40-43]. Vitamin C-dependent miRNA gene regulation has not been studied previously in human BMSCs. For this study, we collected human bone marrow and isolated bone marrow stromal cells. The osteogenic and adipogenic differentiation properties of the cells were analyzed. The BMSCs were treated with vitamin C followed by miRNA array. The selected miRNAs were further conformed using real time-polymerase chain reaction polymerase chain reaction (PCR). Bioinformatics analyses were performed on differentially expressed miRNAs to identify novel target genes and signaling pathways. Our data demonstrated that vitamin $\mathrm{C}$ regulates a number of miRNAs and plays an important role in various stem cell-signaling pathways.

\section{Materials and Methods}

\subsection{Isolation of Human BMSCs (hBMSCs)}

All work described here was approved by the Institutional Review Board and Institutional Biosafety Committee of Augusta University (AU). We collected bone marrow aspirates that were removed as part of orthopedic (total knee, hip, and ACL) surgeries and would normally have been discarded. Bone marrow was obtained under sterile conditions from orthopedic surgery patients $(n=$ 10). The CD271 positive (+) BMSCs were isolated according to the manufacturer's protocol using a kit (Miltenyi Biotec Inc., 130-092-283, Sunnyvale, CA, USA) following previously published methods [44, 45]. The CD271+ MSCs were isolated directly from bone marrow, washed with standard culture medium composed of DMEM medium (Corning, 10-013-CM, NY, USA), 1\% antibiotics-antimycotics (Invitrogen, 15240-062, Carlsbad, CA, USA) and 10\% Fetal bovine serum (FBS), transferred to 100 $\mathrm{mm}$ culture dish and incubated at $37{ }^{\circ} \mathrm{C}$ in a humidified atmosphere at $5 \%$ carbon dioxide $\left(\mathrm{CO}_{2}\right)$. The media with non-adherent cells was removed after $24 \mathrm{~h}$, the adherent cells carefully washed in Phosphate-buffer saline (PBS), and adherent cells further expanded in fresh standard culture medium. Culture-expanded CD271 + BMSCs of passage 1 were used for treating with the vitamin C, miRNA array, quantitative real-time polymerase chain reaction (qPCR) and cell differentiation assay.

\subsection{Osteogenic and Adipogenic Differentiation Assays}

The differentiation potential of cultured hBMSCs into osteogenic and adipogenic lineages was validated in vitro. The osteogenic differentiation [12] and adipogenic assays [2] were performed as per published methods. In brief, cells were plated in 24 -well plates at $5000 \mathrm{cells} / \mathrm{cm}^{2}$ and cultured 
in Dulbecco's Modified Eagle Medium (DMEM) for $24 \mathrm{~h}$. Culture medium was then aspirated and replaced with osteogenic medium. The osteogenic media was prepared in DMEM that was supplemented with 5\% FBS, $0.25 \mathrm{mM}$ ascorbic acid (Sigma-Aldrich, A4544, St. Louis, MO, USA), $0.1 \mathrm{mM}$ dexamethasone (Sigma-Aldrich, D4902, St. Louis, MO, USA), and $10 \mathrm{mM} \beta$-glycerophosphate (Sigma-Aldrich, G9891, St. Louis, MO, USA). The medium was replaced freshly 2 times per week for 3 weeks. Osteogenic differentiation was assessed by staining for bone mineralization with Alizarin Red (AR; Sigma-Aldrich, A5533, St. Louis, MO, USA). The cells were fixed with 10\% formalin for 20 min at room temperature (RT) and stained with $40 \mathrm{mM} \mathrm{AR}, \mathrm{pH} 4.1$ for $20 \mathrm{~min}$ at RT. Stained monolayers were visualized by phase-contrast microscopy using an inverted microscope (Nikon, Melville, NY, USA). Differentiation was quantified as previously described [2]. In brief, cells were destained using $10 \%$ cetylpyridinium chloride (Sigma-Aldrich, C0732, St. Louis, MO, USA). Collected samples were then analyzed with a microplate reader at $590 \mathrm{~nm}$.

For the adipogenic assay, the cultures were incubated in IMDM (Gibco, 12440-046, Waltham, MA, USA) supplemented with 10\% FBS, 10\% Horse Serum (BioAbChem, 720460, Ladson, SC, USA), $12 \mathrm{mM}$ L-glutamine, $5 \mu \mathrm{g} / \mathrm{mL}$ insulin (Cell Application Inc., 128-100, San Diego, CA, USA), $50 \mu \mathrm{M}$ indomethacin (Sigma-Aldrich, I7378, MO, USA), $1 \times 10^{-6} \mathrm{M}$ dexamethasone, and $0.5 \mu \mathrm{M}$ 3-isobutyl-1-methylxanthine (Sigma-Aldrich, I5879, St. Louis, MO, USA). The medium was replaced 2 times per week for 3 weeks followed by real time PCR on adipogenic genes.

\subsection{Vitamin C Treatment, Gene Expression Analysis and Intracellular Vitamin C Estimation}

Human BMSCs were cultured on 24 well plates and treated with or without vitamin C (low $(25 \mu \mathrm{M})$ and high $(100 \mu \mathrm{M})$ concentration) for 6 days. Media was changed every other day with or without vitamin C. Total RNA was isolated for gene expression analysis on both low and high dose vitamin $\mathrm{C}$ treatment groups. Collagen type II, BMP-2, BMP-7, RUNX-2 and OSX gene expressions were performed using real time PCR (Primers' details in supplemental Table S1). Intracellular vitamin C estimation was performed using OxiSelect ${ }^{\mathrm{TM}}$ Ascorbic Acid Assay Kit (FRASC) (Catalog Number, STA-860, Cell Biolabs, Inc., San Diego, CA, USA). Briefly, hBMSCs were treated with (100 $\mu$ M) and without vitamin $\mathrm{C}$ for $6 \mathrm{~h}$ followed by intracellular vitamin $\mathrm{C}$ estimation as per manufacturer's protocol.

\subsection{Microrna Array and Bioinformatics Analysis}

The microRNA array was performed only on samples treated with the high dose $(100 \mu \mathrm{M})$ of vitamin C. miRNAs were isolated using an miRNA isolation kit (SABiosciences Corporation, Frederick, MD, USA) that specifically captures small RNAs with length of less than 200 nucleotides as per the manufacturer's protocol. RNA concentrations were determined using a NanoDrop 1000 Spectrophotometer (NanoDrop Technologies, Wilmington, DE, USA). The quality of RNA samples was characterized on an Agilent BioAnalyzer (Agilent Technologies, Santa Clara, CA, USA) using an RNA6000 Nano Chip (Agilent). Microarrays were performed on miRNA using an Affymetrix GeneChip $^{\circledR}$ miRNA 2.0 array at the Integrated Genomics Core, Augusta University, GA, USA. Details of the procedure can be found online at http://www.augusta.edu/cancer/research/shared/genomics. The miRNA profile was analyzed for hierarchical clustering of miRNA to generate heat maps. The results were normalized using robust multichip averages. T-tests were used to calculate the $p$-value to determine whether there is a significant difference for miRNA expression between the control and the treatment groups. Principal component analysis (PCA) was performed between vitamin C treatment and control samples. Gene Ontology (GO) and Kyoto Encyclopedia of Genes and Genomes (KEGG) signaling pathway analyses were performed using DIANA-miRPath v. 3.0 (http:/ / diana.imis.athena-innovation.gr/DianaTools/index.php) on differentially expressed microRNAs target genes. GO word clouds were generated using the online Wordle software (www.wordle.net). Bioinformatics software (http:/ / www.targetscan.org/vert_71/ and http:/ / www.mirdb.org/) was used to predict targets genes of differentially regulated miRNAs of musculoskeletal importance. 
Validation of miRNA using real time-PCR: Two hundred nanograms of enriched small RNA were converted into cDNA using RT2 miRNA First Strand Kit (SABiosciences Corporation, Frederick, MD, USA). Fifty picograms of cDNA were amplified in each qRT-PCR using syber green dye and miRNA specific primers. The real-time qRT-PCR was performed on a Bio-rad q-pcr machine with following cycling parameters: $95^{\circ} \mathrm{C}$ for $10 \mathrm{~min}$, then 40 cycles of $95^{\circ} \mathrm{C}$ for $15 \mathrm{~s}$, and $60^{\circ} \mathrm{C}$ for $30 \mathrm{~s}$. SYBR Green fluorescence was recorded during the annealing step of each cycle. The average of RNU6 (RNA, U6 small nuclear 2) and SNORD (small nucleolar RNA, C/D box) was used as normalization reference genes for miRNAs. Relative expression of miRNA was evaluated by using the comparative cycle threshold (CT) method $(\Delta \Delta C \mathrm{t})$.

\section{Results}

\subsection{Osteogenic and Adipogenic Differentiation Assays}

Human bone marrow stromal cells showed stem cell characteristics such as adhesion to tissue culture plates, fibroblast-like morphology, and differentiation properties. To identify their differentiation properties, hBMSC were cultured in osteogenic and adipogenic media. For osteogenic properties, cells were treated with osteogenic media for 3 weeks followed by Alizarin red assay staining and real time PCR. Treatment with osteogenic media showed significant $(p=0.01)$ increases Alizarin red staining (Figure 1) and bone specific markers (data not shown). hBMSCs were treated with adipogenic media for 3 weeks showed significantly $(p=0.01)$ elevated levels of adipogenic markers such as PPAR-g2 and Adipsin genes) (Figure 1c).

a)

Osteogenic Assay

c)
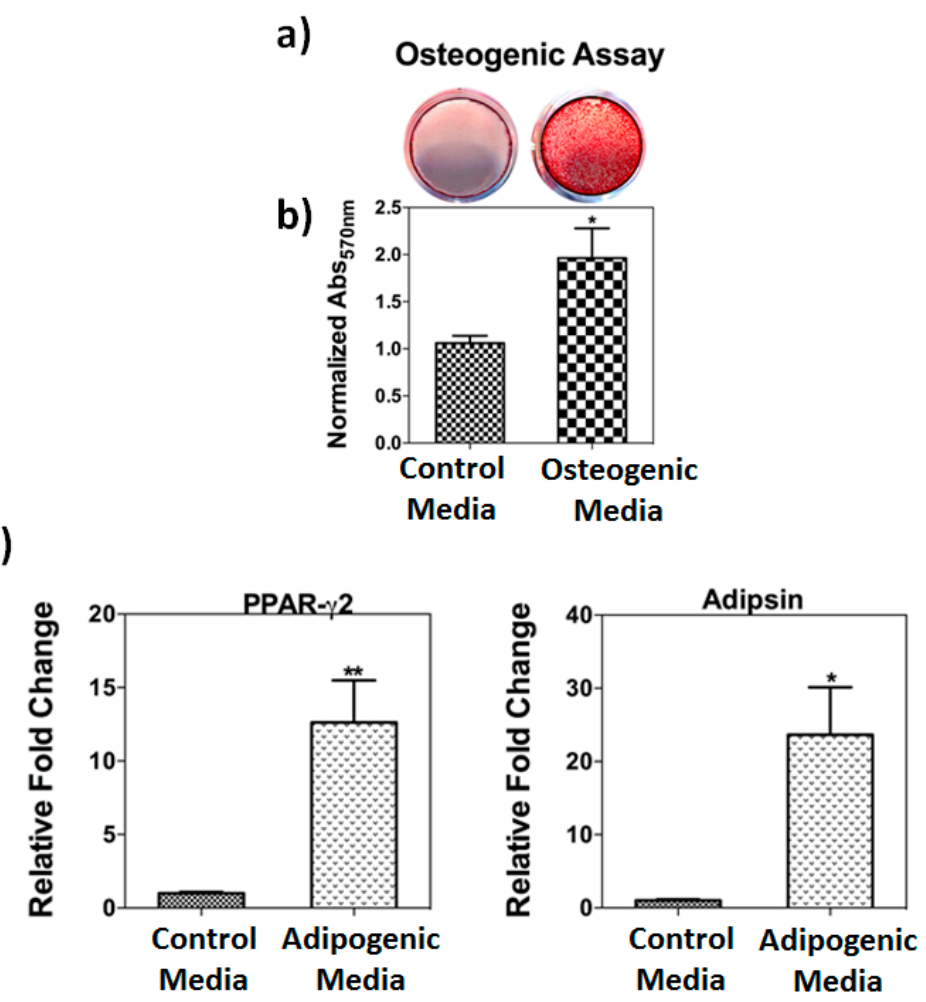

Figure 1. (a) Human bone marrow stromal cells (BMSCs) cultured in osteogenic medium and stained for mineralized nodules using an Alizarin red S assay; (b) Quantitative analysis of the extent of mineralization in the Alizarin red S assay using elution of dye by $10 \%$ (wt./vol.) cetylpyridinium chloride (means $\pm \mathrm{SD}, n=4$ ) (c) Real time PCR analysis of steady-state levels of mRNA for adipogenic genes PPAR-g and adipsin. Data for each sample were normalized with glyceraldehyde-3-phosphate dehydrogenase $(\mathrm{GAPDH})$ mRNA. Data (means $\pm \mathrm{SD}, n=4)$ are represented as the fold change in expression compared to the control. ${ }^{*} p=0.04,{ }^{* *} p=0.01$. 


\subsection{Vitamin C Regulates Musculoskeletal-Related Gene Expression in Hbmscs}

Supplementation of vitamin $C$ is required for the differentiation of hBMSCs but the dose of vitamin $C$ supplementation is debatable. To gain further insight into the dose of vitamin $C$ in the human bone marrow stromal cell culture system, we treated cells with either a low $(25 \mu \mathrm{M})$ or a high $(100 \mu \mathrm{M})$ doses of vitamin $C$ for 6 days followed by real time PCR on musculoskeletal related genes. A higher dose of vitamin $C$ treatment showed the most significant changes in expression of those genes related to osteogenic differentiation. Specifically, COL-II and BMP2 were increased three-fold $(p=0.001)$, where BMP-7, RUNX2 and Osterix (OSX) were up-regulated approximately four-fold $(p=0.001)$ at a higher dose compared to control (Figure 2). Lower doses of vitamin C did not show significant changes (Figure 2). We also quantified intracellular accumulation of vitamin $C$ following vitamin $C$ treatment after $6 \mathrm{hrs}$. We found significantly $(p=0.001)$ higher concentration of intracellular vitamin $\mathrm{C}$ compared to the control (Figure 2f).

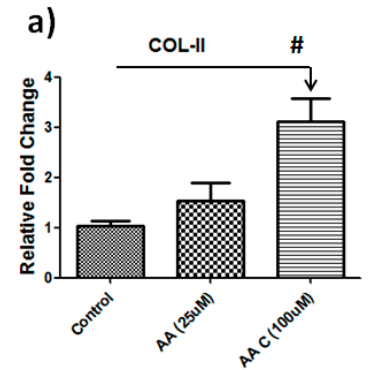

b)

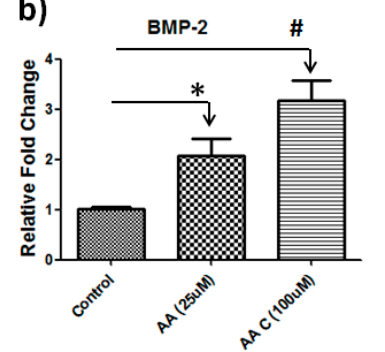

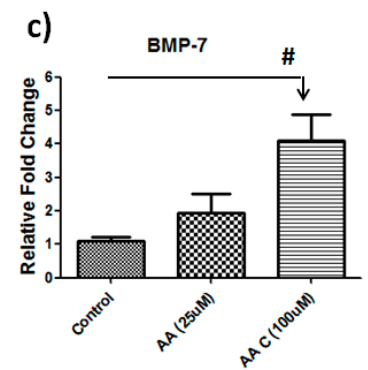
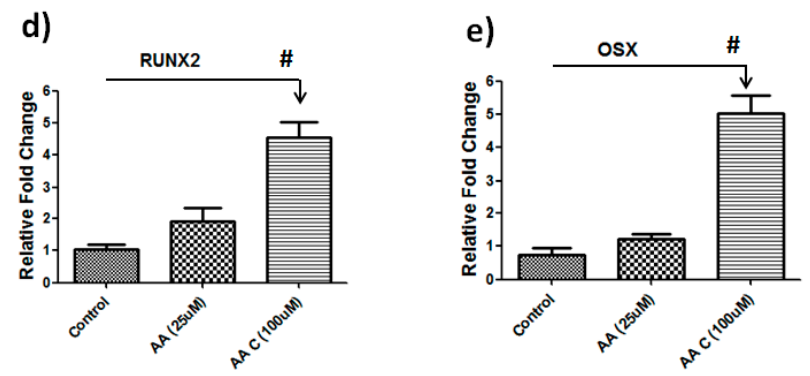

f)

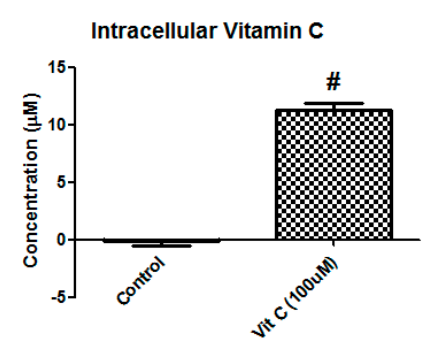

Figure 2. Vitamin C regulates musculoskeletal genes in hBMSCs. Real-time PCR showing dose dependent change in gene expression in hBMSCS after vitamin C treatment (a) Collagen II; (b) BMP-2; (c) BMP-7; (d) RUNX2 and (e) OSX (Osterix). Data $(n=4)$ are represented as the fold change in expression compared with control (* $p=0.04, \# p=0.001$ ); (f) Intracellular concentration of vitamin $C$ in hBMSCs. hBMSCs cells were treated with $100 \mu \mathrm{M}$ vitamin $\mathrm{C}$ and intracellular accumulation of vitamin $C$ was measured in the control and vitamin $C$ treated cells after 6hrs $(n=6, \# p=0.001)$.

\subsection{Global Mirna Expression Profile Following Vitamin C}

To identify miRNAs that were differentially expressed following vitamin $C$ treatment, we conducted a comprehensive miRNA microarray analysis of samples from hBMSCs that were treated with or without vitamin C. miRNAs were isolated after 6 days post treatment. The miRNAs that 
exhibited a significant $(p<0.05) 1.5$-fold difference in expression after vitamin $C$ treatment compared with the control groups were selected for analysis. Our analysis identified 122 miRNAs that were differentially expressed $(p<0.05)$ in response to vitamin C. Out of 122 miRNAs, 80 miRNAs were up-regulated and 42 were down-regulated in the presence of vitamin $C$. The list of up-regulated and down-regulated miRNAs after vitamin $C$ treatment is shown in Table 1. Hierarchical cluster analysis using the normalized miRNA expression data confirmed that the expression of miRNAs in vitamin in $\mathrm{C}$ treated BMSCs can be clearly distinguished from the controls (Figure 3).

\subsection{Principal Component Analysis (PCA)}

We performed a PCA to explore the relationships between the control and vitamin C-treated samples. The PCA graph (Figure 3) shows the presence of the cluster of vitamin C treatment samples that is clearly distinct from the control (non-treated) samples.

Table 1. Selected miRNAs differentially regulated in presence of vitamin $\mathrm{C}$ in human bone marrow stromal cells.

\begin{tabular}{ccc}
\hline MicroRNA ID/Probeset ID & Fold-Change & $p$-Value \\
\hline hsa-miR-3651_st & -3.76469 & 0.000718 \\
hsa-miR-4485_st & -3.70276 & 0.002619 \\
hsa-miR-1275_st & -3.00098 & 0.022393 \\
hsa-miR-4708-5p_st & -2.94613 & 0.002456 \\
hsa-miR-3197_st & -2.86102 & 0.048879 \\
hsa-miR-720_st & -2.81658 & 0.019125 \\
hsa-miR-210_st & -2.75739 & 0.001763 \\
hsa-miR-29b-1-star_st & -2.71192 & 0.032586 \\
hsa-miR-4284_st & -2.49253 & 0.003259 \\
hsa-miR-4479_st & -2.39325 & 0.026759 \\
hsa-miR-3175_st & -2.37271 & 0.013122 \\
hsa-miR-4730_st & -2.36644 & 0.009171 \\
hsa-miR-23a-star_st & -2.26148 & 0.001843 \\
hsa-miR-4321_st & -2.25569 & 0.024075 \\
hp_hsa-mir-3676_st & -2.13436 & 0.008900 \\
hsa-miR-4787-3p_st & -2.05594 & 0.003156 \\
hsa-miR-574-5p_st & -2.02613 & 0.019283 \\
hsa-miR-4492_st & -1.99221 & 0.011873 \\
hsa-miR-345_st & -1.96585 & 0.019316 \\
hsa-miR-1270_st & -1.90283 & 0.047187 \\
hsa-miR-4697-5p_st & -1.83134 & 0.039445 \\
hsa-miR-4433_st & -1.80613 & 0.005357 \\
hp_hsa-mir-4477a_st & 1.83543 & 0.0351021 \\
hp_hsa-mir-548ag-2_st & 1.83747 & 0.0217069 \\
hsa-miR-4727-3p_st & 1.86033 & 0.0446828 \\
hsa-miR-335_st & 1.86288 & 0.0415722 \\
hsa-miR-202_st & 1.87834 & 0.00218913 \\
hsa-miR-4436a_st & 1.96484 & 0.00880198 \\
hp_hsa-mir-532_st & 1.98369 & 0.035662 \\
hsa-miR-3942-5p_st & 1.98754 & 0.002823 \\
hsa-miR-3163_st & 2.0011 & 0.019565 \\
hp_hsa-mir-548f-1_st & 2.01894 & 0.026558 \\
hsa-miR-92a-2-star_st & 2.02393 & 0.003107 \\
hsa-miR-548a-3p_st & 2.02776 & 0.003973 \\
hsa-miR-3121-3p_st & 2.03509 & 0.007681 \\
hsa-miR-3201_st & 2.07949 & 0.006952 \\
hsa-miR-4657_st & 2.07988 & 0.027179 \\
hsa-miR-4704-5p_st & 2.10426 & 0.002415 \\
hsa-miR-1825_st & 2.1387 & 0.028925 \\
hsa-miR-550a-star_st & 2.16711 & 0.017221 \\
\hline has & & \\
\hline
\end{tabular}


Table 1. Cont.

\begin{tabular}{ccc}
\hline MicroRNA ID/Probeset ID & Fold-Change & $p$-Value \\
\hline hsa-miR-1323_st & 2.21591 & 0.006721 \\
hsa-miR-3927_st & 2.23141 & 0.002801 \\
hsa-miR-509-3-5p_st & 2.2723 & 0.003025 \\
hsa-miR-4423-3p_st & 2.27939 & 0.030500 \\
hsa-miR-890_st & 2.34751 & 0.035107 \\
hsa-miR-4773_st & 2.41459 & 0.002370 \\
hsa-miR-371b-5p_st & 2.42868 & 0.038520 \\
hsa-miR-3128_st & 2.49419 & 0.014536 \\
hsa-miR-1272_st & 2.59151 & 0.033417 \\
hsa-miR-4659a-3p_st & 2.60253 & 0.005995 \\
hsa-miR-377_st & 2.64791 & 0.003494 \\
hsa-miR-550b_st & 2.68252 & 0.013600 \\
hsa-miR-20b-star_st & 2.76807 & 0.004101 \\
hsa-miR-3152-3p_st & 3.2214 & 0.002098 \\
hsa-miR-1208_st & 5.02485 & 0.010838 \\
hsa-miR-4529-3p_st & 12.0104 & 0.009329 \\
\hline
\end{tabular}

a)

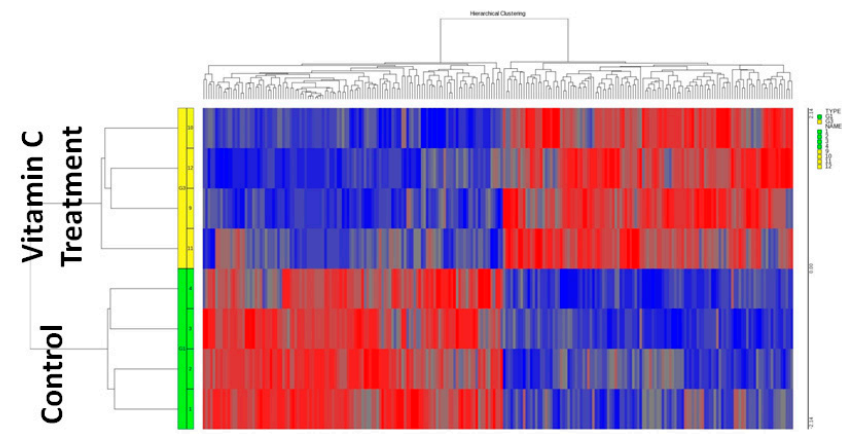

b)

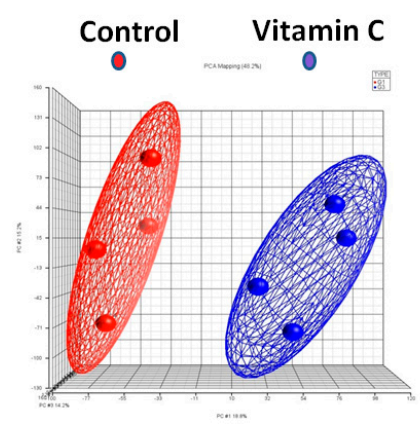

Figure 3. Differential miRNA expression in human bone marrow stromal cells after vitamin $C$ treatment ( $n=4$ each group). (a) The heat-map showing the differential expression pattern of miRNAs compared to control group; (b) Principle component analysis (PCA) mapping of vitamin C treatment and control samples. Control group (indicated by red color) was clustered distinctly from vitamin $\mathrm{C}$ treated group (indicated by blue color).

\subsection{Validation of Differentially Expressed Mirnas}

To further verify the results obtained from miRNA microarrays, we performed real-time PCR on five randomly selected miRNAs to validate our findings. MiRNA real-time PCR showed similar changes as noted in miRNA array (Figure 4$)$. In vitamin $C(100 \mu \mathrm{M})$ - treated samples, we found that miR-29b $(p=0.04)$ and miR-4705 ( $p=0.04)$ were significantly down-regulated and miR-3942 $(p=0.01)$ and miR-3152 ( $p=0.04)$ were significantly up-regulated whereas miRNA-371b showed a 
trend of up-regulation similar to our array findings. Low dose vitamin $C(25 \mu \mathrm{M})$ treatment did not show significant changes in any of the above-mentioned miRNA expression analyses (supplementary Figure S1).
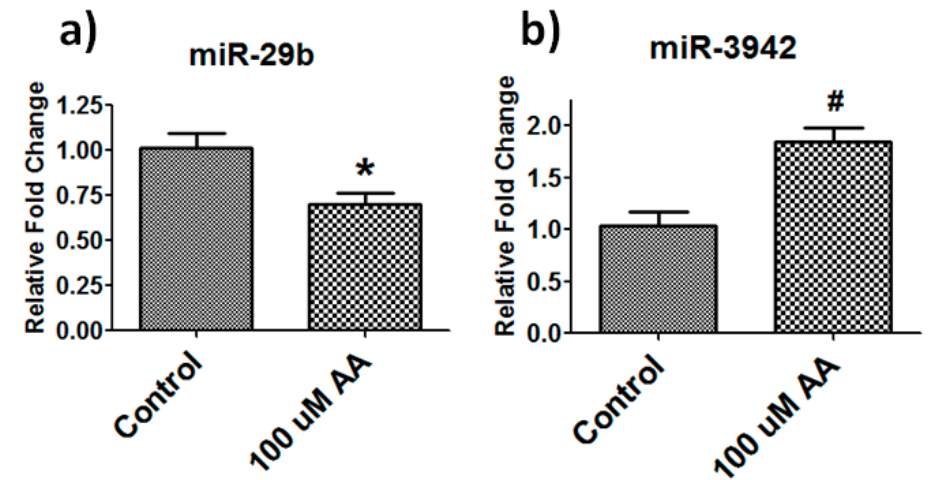

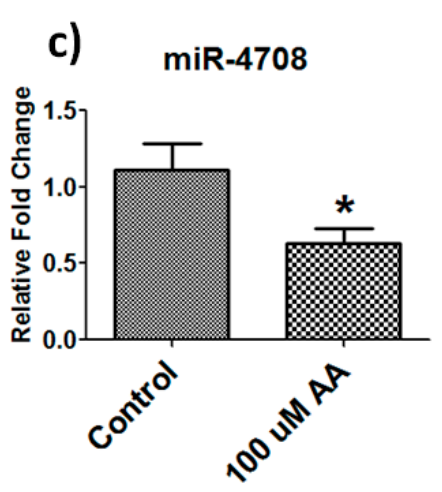

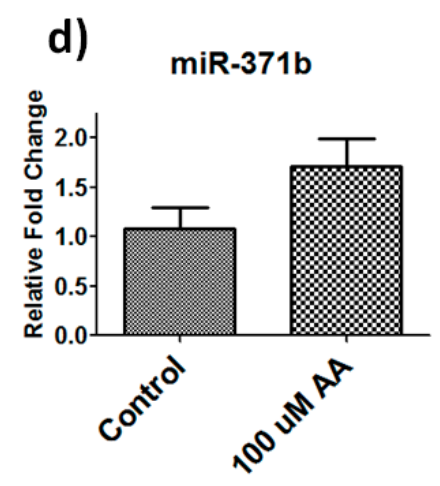

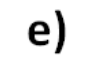

miR-3152

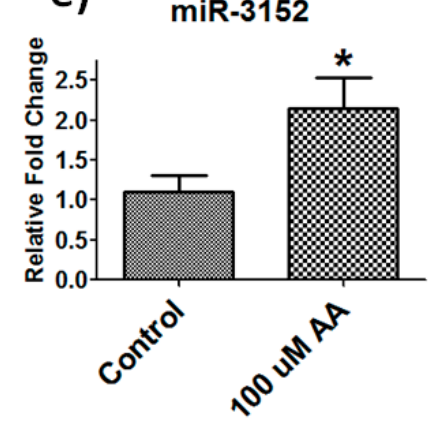

Figure 4. Validation of miRNA array data on randomly picked miRNAs. Real-time PCR showing change in miRNA expression in vitamin $C(100 \mu \mathrm{M})$ treated samples compared to control (a) miR-29b; (b) $\mathrm{miR}-3942 ;$ (c) miR-4708; (d) $\mathrm{miR}-371 \mathrm{~b}$ and (e) miR-3152 ( $n=4-6,{ }^{*} p=0.05$, \# $p=0.01$ ).

\subsection{Signaling Pathway Predictions}

We performed Kyoto Encyclopedia of Genes and Genomes (KEGG) pathway annotation and GO analysis to identify functions of the miRNAs found to be differentially expressed after vitamin $\mathrm{C}$ treatment. The KEGG annotation analysis showed that a number of molecules are affected by these miRNAs. Interestingly, up-regulated and down-regulated miRNAs both regulate some common signaling pathways such as cell adhesion molecules (CAMs), fatty acid biosynthesis/metabolism and thyroid hormone signaling pathway. The important KEGG signaling for up-regulated miRNAs are Mucin type O-Glycan biosynthesis, glycosphingolipid biosynthesis, biotin metabolism and arrhythmogenic right ventricular cardiomyopathy (ARVC) and down-regulated are amino sugar and nucleotide sugar metabolism, endocytosis, MAPK signaling pathway, GABAergic synapse, and glutamatergic synapse. Details of KEGG annotation analysis are shown in Table 2.

Table 2. Selected KEGG biological pathways potentially affected by (a) miRNAs down-regulated; and (b) miRNAs up-regulated in the presence of vitamin $C$ in human bone marrow stromal cells.

\begin{tabular}{cccc}
\hline & (a) & & \\
\hline KEGG Pathway & $p$-Value & Number of Genes Involved & Number of miRNAs Involved \\
\hline Prion diseases & $4.07 \times 10^{-10}$ & 7 & 7 \\
Morphine addiction & $4.80 \times 10^{-5}$ & 32 & 17 \\
Amino sugar and nucleotide sugar metabolism & 0.002142 & 16 & 11 \\
Thyroid hormone signaling pathway & 0.002958 & 37 & 17 \\
Cell adhesion molecules (CAMs) & 0.006179 & 43 & 16 \\
Endocytosis & 0.009192 & 63 & 18 \\
\hline
\end{tabular}


Table 2. Cont

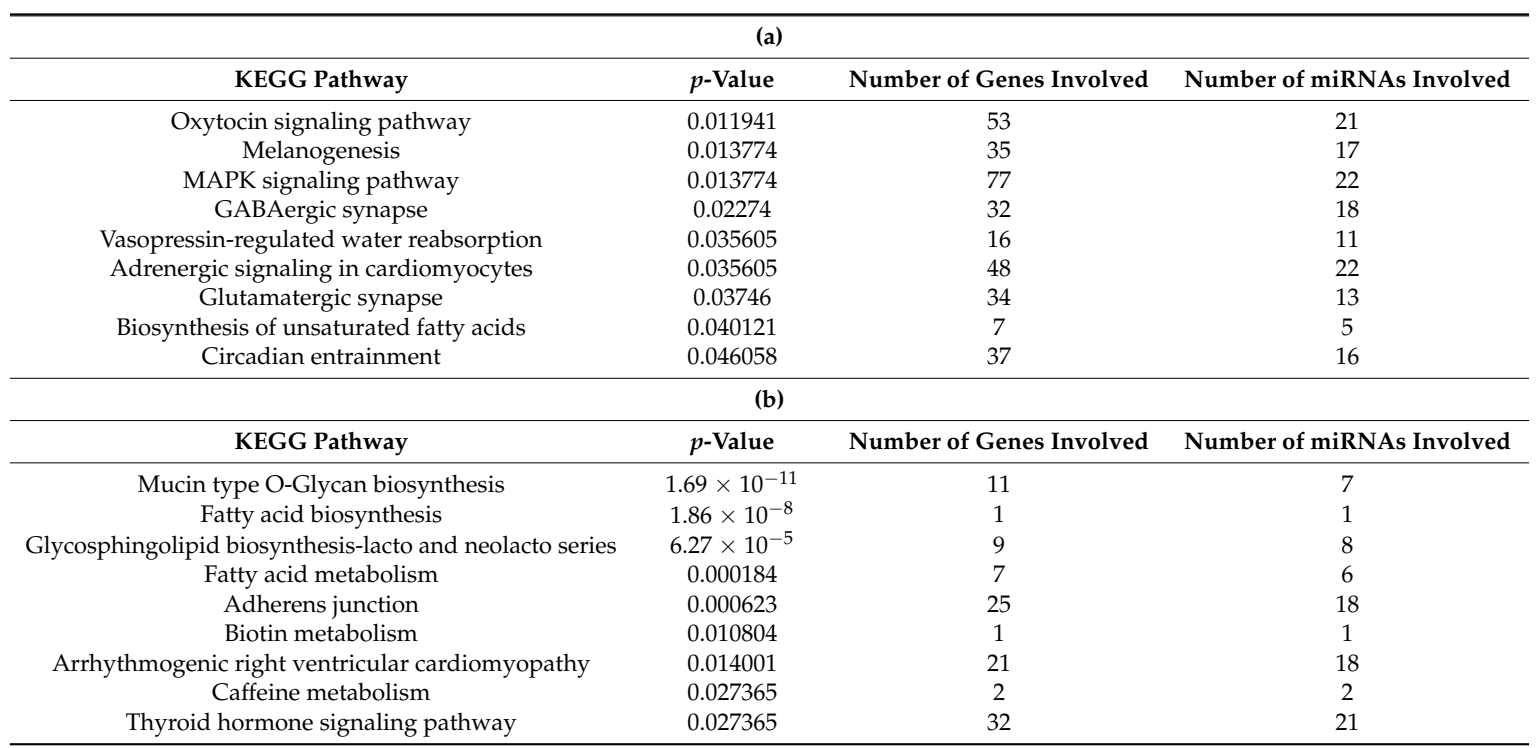

The gene ontology analysis showed that more than 87 biological processes were associated with the down- and up-regulated miRNAs (Table 3). The most common GO pathways regulated by both up-regulated and down-regulated miRNAs are organelles, biosynthetic processes, cellular protein modification process, enzyme binding, cellular component assembly and nucleic acid binding transcription factor activity. Details of the GO analyses are shown in Table 3. Wordle-based clouds were generated for both up-regulated and down-regulated pathways from the GO analysis to identify most prominent vitamin C-dependent, miRNA-mediated signaling pathways (Figure S2). Word clouds demonstrate the font size depending on relative word frequencies in the GO analysis [46].

Table 3. Selected (firsts 50) gene ontology (GO) biological pathways potentially affected by (a) miRNAs down-regulated; and (b) miRNAs up-regulated in the presence of vitamin $\mathrm{C}$ in human bone marrow stromal cells.

\begin{tabular}{|c|c|c|c|}
\hline \multicolumn{4}{|l|}{ (a) } \\
\hline GO Category & $p$-Value & Genes & miRNAs \\
\hline organelle & $1.15 \times 10^{-87}$ & 2073 & 24 \\
\hline ion binding & $7.43 \times 10^{-46}$ & 1270 & 25 \\
\hline cellular nitrogen compound metabolic process & $7.82 \times 10^{-45}$ & 1006 & 24 \\
\hline biosynthetic process & $1.56 \times 10^{-32}$ & 856 & 24 \\
\hline small molecule metabolic process & $1.56 \times 10^{-17}$ & 489 & 24 \\
\hline cellular protein modification process & $3.92 \times 10^{-15}$ & 475 & 24 \\
\hline neurotrophin TRK receptor signaling pathway & $2.05 \times 10^{-14}$ & 70 & 18 \\
\hline synaptic transmission & $2.05 \times 10^{-14}$ & 121 & 21 \\
\hline nucleic acid binding transcription factor activity & $1.32 \times 10^{-13}$ & 231 & 24 \\
\hline cellular protein metabolic process & $2.55 \times 10^{-11}$ & 106 & 20 \\
\hline cell-cell signaling & $1.27 \times 10^{-10}$ & 162 & 24 \\
\hline catabolic process & $1.50 \times 10^{-10}$ & 390 & 24 \\
\hline cellular component assembly & $2.41 \times 10^{-9}$ & 272 & 23 \\
\hline molecular_function & $2.43 \times 10^{-9}$ & 3342 & 25 \\
\hline gene expression & $2.95 \times 10^{-9}$ & 116 & 22 \\
\hline symbiosis, encompassing mutualism through parasitism & $4.66 \times 10^{-9}$ & 111 & 21 \\
\hline post-translational protein modification & $4.93 \times 10^{-9}$ & 46 & 17 \\
\hline cellular_component & $5.00 \times 10^{-9}$ & 3383 & 25 \\
\hline blood coagulation & $1.28 \times 10^{-8}$ & 101 & 20 \\
\hline viral process & $2.94 \times 10^{-8}$ & 97 & 21 \\
\hline protein binding transcription factor activity & $7.72 \times 10^{-8}$ & 110 & 22 \\
\hline macromolecular complex assembly & $1.45 \times 10^{-7}$ & 185 & 23 \\
\hline
\end{tabular}


Table 3. Cont.

\begin{tabular}{|c|c|c|c|}
\hline \multicolumn{4}{|l|}{ (a) } \\
\hline GO Category & $p$-Value & Genes & miRNAs \\
\hline enzyme binding & $1.74 \times 10^{-7}$ & 261 & 23 \\
\hline Fc-epsilon receptor signaling pathway & $5.08 \times 10^{-7}$ & 38 & 15 \\
\hline response to stress & $1.46 \times 10^{-6}$ & 437 & 25 \\
\hline toll-like receptor TLR1:TLR2 signaling pathway & $2.79 \times 10^{-6}$ & 21 & 10 \\
\hline toll-like receptor TLR6:TLR2 signaling pathway & $2.79 \times 10^{-6}$ & 21 & 10 \\
\hline toll-like receptor 10 signaling pathway & $3.62 \times 10^{-6}$ & 20 & 10 \\
\hline membrane organization & $5.32 \times 10^{-6}$ & 121 & 23 \\
\hline energy reserve metabolic process & $8.12 \times 10^{-6}$ & 30 & 13 \\
\hline TRIF-dependent toll-like receptor signaling pathway & $1.46 \times 10^{-5}$ & 21 & 10 \\
\hline protein complex assembly & $1.95 \times 10^{-5}$ & 158 & 23 \\
\hline MyD88-independent toll-like receptor signaling pathway & $2.89 \times 10^{-5}$ & 22 & 11 \\
\hline protein complex & $3.71 \times 10^{-5}$ & 708 & 24 \\
\hline toll-like receptor 5 signaling pathway & $3.75 \times 10^{-5}$ & 20 & 10 \\
\hline toll-like receptor 9 signaling pathway & $4.84 \times 10^{-5}$ & 21 & 10 \\
\hline Golgi lumen & $5.79 \times 10^{-5}$ & 26 & 11 \\
\hline O-glycan processing & $7.15 \times 10^{-5}$ & 18 & 12 \\
\hline immune system process & 0.000127 & 309 & 25 \\
\hline mitotic cell cycle & 0.00013 & 74 & 19 \\
\hline cytoskeletal protein binding & 0.000137 & 155 & 22 \\
\hline generation of precursor metabolites and energy & 0.000171 & 74 & 18 \\
\hline regulation of rhodopsin mediated signaling pathway & 0.000201 & 12 & 10 \\
\hline toll-like receptor 4 signaling pathway & 0.000201 & 26 & 11 \\
\hline inositol phosphate metabolic process & 0.000219 & 17 & 9 \\
\hline nucleobase-containing compound catabolic process & 0.000385 & 168 & 24 \\
\hline toll-like receptor 2 signaling pathway & 0.000449 & 21 & 10 \\
\hline platelet degranulation & 0.000563 & 20 & 15 \\
\hline glycosaminoglycan metabolic process & 0.000573 & 26 & 13 \\
\hline platelet activation & 0.000643 & 44 & 18 \\
\hline \multicolumn{4}{|l|}{ (b) } \\
\hline GO Category & $p$-Value & Genes & miRNAs \\
\hline organelle & $1.67 \times 10^{-95}$ & 2091 & 47 \\
\hline ion binding & $3.27 \times 10^{-55}$ & 1303 & 47 \\
\hline cellular nitrogen compound metabolic process & $7.65 \times 10^{-47}$ & 1010 & 46 \\
\hline biosynthetic process & $1.19 \times 10^{-35}$ & 866 & 46 \\
\hline gene expression & $7.04 \times 10^{-23}$ & 151 & 38 \\
\hline cellular protein modification process & $1.18 \times 10^{-22}$ & 507 & 46 \\
\hline small molecule metabolic process & $7.20 \times 10^{-18}$ & 488 & 45 \\
\hline nucleic acid binding transcription factor activity & $1.08 \times 10^{-12}$ & 227 & 43 \\
\hline molecular_function & $2.35 \times 10^{-11}$ & 3343 & 48 \\
\hline cellular_component & $8.85 \times 10^{-10}$ & 3375 & 48 \\
\hline cellular protein metabolic process & $1.27 \times 10^{-9}$ & 101 & 35 \\
\hline enzyme binding & $1.33 \times 10^{-9}$ & 272 & 43 \\
\hline protein binding transcription factor activity & $5.19 \times 10^{-9}$ & 114 & 37 \\
\hline cellular component assembly & $9.08 \times 10^{-9}$ & 268 & 42 \\
\hline viral process & $1.39 \times 10^{-8}$ & 98 & 31 \\
\hline blood coagulation & $2.54 \times 10^{-8}$ & 100 & 35 \\
\hline symbiosis, encompassing mutualism through parasitism & $6.42 \times 10^{-8}$ & 107 & 32 \\
\hline neurotrophin TRK receptor signaling pathway & $9.66 \times 10^{-8}$ & 56 & 28 \\
\hline catabolic process & $9.95 \times 10^{-8}$ & 371 & 44 \\
\hline cell death & $3.44 \times 10^{-7}$ & 195 & 40 \\
\hline protein complex & $5.91 \times 10^{-7}$ & 724 & 46 \\
\hline enzyme regulator activity & $7.70 \times 10^{-7}$ & 179 & 36 \\
\hline platelet activation & $9.11 \times 10^{-7}$ & 52 & 25 \\
\hline membrane organization & $2.77 \times 10^{-6}$ & 122 & 36 \\
\hline post-translational protein modification & $3.62 \times 10^{-6}$ & 40 & 23 \\
\hline Fc-gamma receptor signaling pathway involved in phagocytosis & $4.22 \times 10^{-6}$ & 22 & 13 \\
\hline cytoskeletal protein binding & $1.60 \times 10^{-5}$ & 160 & 37 \\
\hline nucleoplasm & $1.79 \times 10^{-5}$ & 233 & 43 \\
\hline cytosol & $2.00 \times 10^{-5}$ & 523 & 43 \\
\hline
\end{tabular}


Table 3. Cont

\begin{tabular}{|c|c|c|c|}
\hline \multicolumn{4}{|l|}{ (b) } \\
\hline GO Category & $p$-Value & Genes & miRNAs \\
\hline cell junction organization & $2.35 \times 10^{-5}$ & 42 & 24 \\
\hline nucleobase-containing compound catabolic process & $3.39 \times 10^{-5}$ & 174 & 41 \\
\hline transmembrane transporter activity & $3.63 \times 10^{-5}$ & 219 & 38 \\
\hline macromolecular complex assembly & $3.63 \times 10^{-5}$ & 172 & 39 \\
\hline toll-like receptor TLR1:TLR2 signaling pathway & $5.04 \times 10^{-5}$ & 19 & 15 \\
\hline toll-like receptor TLR6:TLR2 signaling pathway & $5.04 \times 10^{-5}$ & 19 & 15 \\
\hline TRIF-dependent toll-like receptor signaling pathway & $5.32 \times 10^{-5}$ & 20 & 16 \\
\hline toll-like receptor 10 signaling pathway & $6.86 \times 10^{-5}$ & 18 & 15 \\
\hline Fc-epsilon receptor signaling pathway & $8.73 \times 10^{-5}$ & 33 & 19 \\
\hline cellular component disassembly involved in execution phase of apoptosis & 0.000104 & 15 & 11 \\
\hline vitamin metabolic process & 0.000237 & 21 & 19 \\
\hline MyD88-independent toll-like receptor signaling pathway & 0.000351 & 20 & 16 \\
\hline homeostatic process & 0.000351 & 168 & 41 \\
\hline mitotic cell cycle & 0.000368 & 72 & 34 \\
\hline protein complex assembly & 0.000392 & 150 & 37 \\
\hline water-soluble vitamin metabolic process & 0.000403 & 19 & 17 \\
\hline toll-like receptor 5 signaling pathway & 0.000491 & 18 & 15 \\
\hline energy reserve metabolic process & 0.000538 & 26 & 18 \\
\hline glycerophospholipid biosynthetic process & 0.000692 & 23 & 14 \\
\hline activation of signaling protein activity involved in unfolded protein response & 0.000692 & 18 & 16 \\
\hline transcription initiation from RNA polymerase II promoter & 0.000793 & 52 & 25 \\
\hline toll-like receptor 9 signaling pathway & 0.001896 & 18 & 15 \\
\hline
\end{tabular}

\subsection{Bioinformatics Mirna Target Prediction}

Based on miRNA targets predicted from the in silico analysis, we can derive some functional predictions of the differentially regulated miRNAs. We analyzed the potential targets of miRNAs that are differentially expressed following vitamin $C$, with the criteria that the miRNAs must bind the $3^{\prime}$-UTR of the mRNA with its seed sequence. We used Targetscan.org and mirdb.org target prediction tools to identify miRNA targets and their signaling pathways. We identified a number of miRNA targets of musculoskeletal and stem cell differentiation related genes. The lists of miRNA targets are shown in Table 4.

Table 4. Predicated targets of differentially regulated miRNAs of stem cell biology.

\begin{tabular}{cccl}
\hline \multirow{2}{*}{ miRNA } & \multicolumn{2}{c}{ No. of Targets } & \multicolumn{1}{c}{ Stem Cell Related Genes } \\
\cline { 2 - 4 } & MiRDB Scan & Target Scan & \multicolumn{1}{c}{ Common Targets } \\
\hline hsa-miR-3619-5p & 788 & 5948 & $\begin{array}{l}\text { PPARGC1B, RUNX3, DLX3, TGFBRAP1, TNFAIP1, TRAF1, TRAF3, } \\
\text { TRAF5, TNFAIP8L1, MMP24, SOX8, QSOX2, WNT3 }\end{array}$ \\
\hline hsa-miR-548a-3p & 947 & 6717 & $\begin{array}{l}\text { BMPR2, TGFBR3, TGFBR1, TAB2, TWISTNB, CDC42BPB, IL6R, TRAF6, } \\
\text { SMAD4, SMAD1, SMAD5, MMP2, WNT3 }\end{array}$ \\
\hline hsa-miR-3942-5p & 437 & 3758 & DLX1, BMPR2, BMP2K, TGFB2, IL6R, TNFRSF11A, TRAF3, SMAD1 \\
\hline hsa-miR-4741 & 253 & 4549 & TAB2, SMURF1, SNIP1 \\
\hline hsa-miR-1825 & 253 & 4160 & PPARD, RUNX2, TGFBRAP1, TGFBR1, CD40, SOX6 \\
\hline hsa-miR-1208 & 304 & 4651 & TGFB2, TWISTNB, SMURF1, MMP16, LEPROT \\
\hline
\end{tabular}

\section{Discussion}

Adult bone marrow stromal cells are an important cell type in regenerative, cell-based therapeutics [47]. Differentiation and regenerative capabilities of BMSCs can be enhanced by manipulating the cellular micro-environment. One goal of regenerative medicine is to optimize the regenerative potential of BMSCs through nutritional supplementation [4-15]. Vitamin C is one of the most important players in cell proliferation, differentiation, extracellular matrix (ECM) synthesis and cytoskeletal development [21-24]. We hypothesized that supplementation of vitamin C might regulate 
miRNA-dependent gene regulation. A number of reports have demonstrated that micronutrients such as vitamin E, D and amino acid derivatives regulate miRNA-dependent gene expression in various cell types [48-52]. Kim et al. (2015) recently demonstrated that dietary supplementation of a high dose of vitamin $C$ resulted in enhanced anti-senescence and anti-atherosclerotic effects via regulation of anti-inflammatory microRNA [53]. Goa et al. (2014) reported that vitamin C induces a pluripotent state in mouse embryonic stem cells by modulating microRNA expression [54]. Another investigator also noted differential miRNA expression in vitamin C-deficient (L-gulonogammalactone oxidase knockout) C57BL6 mice during follicular maturation [55].

To our knowledge, no study has investigated the effect(s) of vitamin C-dependent miRNA regulation on human bone marrow stromal cells. Hence, identification of vitamin C-dependent microRNA regulation is important for understanding the basic mechanisms underlying BMSC differentiation and tissue engineering. We identified a list of miRNAs that were differentially expressed following vitamin $\mathrm{C}$ treatment $(100 \mu \mathrm{M}$ dose). Principal component analysis (PCA) showed that control samples are clustered together and clearly separated from vitamin $C$ treatment groups. To further verify our miRNA array data, we randomly selected five miRNAs and performed real time PCR for further confirmation. Real-time PCR showed similar patterns of differential expression identical to those seen with the miRNA Array data.

Vitamin $C$ is an essential nutrient that is not synthesized by most mammals including humans; therefore, the dietary supplementation of vitamin $C$ is required for normal cell function. One outstanding question regarding vitamin $C$ supplementation is what doses promote the optimal differentiation of human BMSCs. Our data demonstrate that a higher doses $(100 \mu \mathrm{M})$ of vitamin C effectively activate musculoskeletal-related genes in human BMSCs whereas lower doses $(25 \mu \mathrm{M})$ of vitamin C did not. Similar results were also noted for vitamin C-dependent miRNA regulation. At lower doses of vitamin $C$, we did not find a significant change in miRNA expression comparable to what we observed with the higher $100 \mu \mathrm{M}$ dose. Our study suggested that dose of vitamin $\mathrm{C}(100 \mu \mathrm{M})$ is important to achieve miRNA and gene expression changes in human BMSCs.

We correlated our miRNA data with published literature to gain additional insights into the role(s) of these differentially regulated miRNAs in stem cell biology. Scientific literature suggests that miRNAs differentially regulated by vitamin $C$ have an important role in mouse and human stem cell biology. Di Fiore et al (2014) reported that miR-29b-1 regulates cell proliferation, clonogenic growth, and migration ability of osteosarcoma cells, through negative regulation of stemness markers (Oct3/4, Sox2 and Nanog) [56]. Zhang et al. (2016) demonstrated that miR-589-5p inhibits MAP3K8 and suppresses CD90+ cancer stem cells in hepatocellular carcinoma [57]. Both miR-29b-1 and miR-589-5p are down-regulated in vitamin C-treated human BMSCs. There is a possibility that vitamin $C$ treatment down-regulates miR-29b-1 and miR-589-5p and promotes Oct3/4, Sox2, Nanog and SOX2 and MAP3K8 expression respectively in hBMSCs and helps in cell proliferation and differentiation. Moreover, Quan et al. (2017) showed that human alveolar progenitor type II cell (ATIC)-derived exosomal miR-371b-5p promotes ATIIC-specific stem cells proliferation by targeting PTEN (phosphatase and tensin homolog) [58]. Su et al. (2015) demonstrated that miR-181a inhibits differentiation of HL-60 cells and CD34+ hematopoietic stem/progenitor cells by directly targeting PRKCD-P38-C/EBP $\alpha$ pathway [59] and Jones et al. (2015) reported that miR-215 target caudal-type homeobox 1 (CDX1) and regulates colorectal cancer stem cell differentiation [60]. The above mentioned miRNAs (miR-371b-5p, miR-181a and miR-215) were up-regulated with treatment of vitamin C to hBMSCs. We speculate that these miRNAs target PTEN, PRKCD-P38-C/EBP $\alpha$ and CDX1, respectively, and promote cell proliferation and differentiation of BMSCs. Figure 5 showing possible vitamin $C$ dependent miRNAs mediated signaling in bone marrow stromal cells based on published verified targets. 


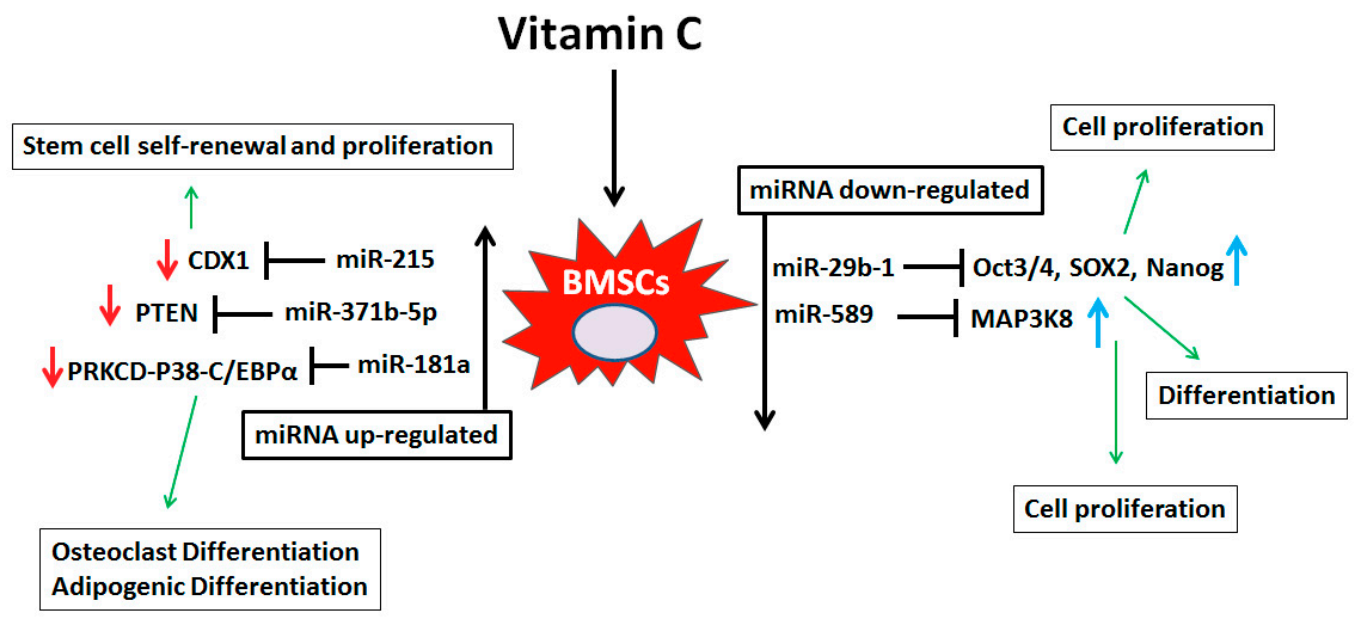

Figure 5. Vitamin C dependent miRNAs mediated signaling in human bone marrow stromal cells. Schematic diagram showing the contribution of key miRNAs in cell proliferation and differentiation of human bone marrow stromal cell.

Our miRNA array data identified a number of novel miRNAs; their functions are not well-understood. In order to determine the potential role(s) of miRNAs involved in hBMSCs exposed to vitamin C, we analyzed the predicted target genes of selected miRNAs. Bioinformatics analysis is an important tool for identifying the predicted role of novel miRNAs. We focused on selected miRNAs: miR-3619-5p, miR-548a-3p, miR-3942-5p, miR-4741, miR-1825, and miR-1208. After bioinformatics analysis, we found that these miRNAs target a number of genes that are important for regulating stem cell differentiation, particularly with regard to lineage commitment in musculoskeletal tissues (See Table 4). MicroRNA gene regulation is a complex process. It is well known that a single miRNA can target a number of genes, and a single gene is targeted by a number of miRNAs. We hypothesized that vitamin C dependent hBMSC cell proliferation and differentiation is partly regulated by these novel miRNAs.

To determine the biological function of miRNAs that are differentially expressed by vitamin C, KEGG pathway annotation and GO analysis were performed to analyze their target gene pools. KEGG annotation revealed that a number of signaling molecules are regulated by vitamin $C$ treatment. Perhaps the most important signaling molecules are cell adhesion molecules (CAMs), fatty acid biosynthesis/metabolism and thyroid hormone signaling pathway molecules. These signaling molecules are regulated by both down-regulated and up-regulated miRNAs. Previously, Pustylnik et al. (2013) demonstrated that vitamin $C$ induces the expression of cell adhesion molecules and stimulates the differentiation of osteoblasts [61]. Furthermore, it has been previously reported that supplementation of vitamin C improves the thyroid hormone level in hypothyroidism patients [62]. Dysregulation of thyroid hormone is involved in various musculoskeletal pathologies such as osteoporosis [63,64]. Our KEGG signaling analysis indicated that vitamin $C$ might regulate miRNAs of thyroid hormone importance and may participate in bone metabolism. Bayerle-Eder et al. (2004) reported that supplementation with vitamin $\mathrm{C}$ improves lipid-induced impairment of endothelium-dependent vasodilation [65] and Ginter et al. (1969) demonstrated that chronic vitamin C deficiency affects the fatty acid composition of blood serum, liver triglyceride and cholesterol [66]. Fatty acids and their metabolites are important factors in stem cell proliferation and differentiation $[67,68]$. Our study indicates that vitamin C-induced miRNAs might have a substantial role in fatty acid-dependent signaling in BMSC cell biology. Moreover, the GO analysis showed that vitamin $C$ is involved in a number of cellular metabolic processes (such as protein biosynthesis, cellular functions, enzyme biosynthesis, cell cycle) and signaling (such as TLR, TRK, and MAPK signaling) (Table 3). These cellular metabolic processes and signaling are vital in BMSC proliferation and differentiation. 


\section{Conclusions}

To our knowledge, our study is the first report to identify vitamin C-dependent differential novel miRNA expression in hBMSCs. We also provide new data linking these miRNAs to key signaling pathways involved in BMSC biology. We believe our study is a key step in gaining a greater understanding of how vitamin $\mathrm{C}$ contributes to hBMSC biology through the miRNA signaling network. Our study has some limitations. For example, we performed the study only on human bone marrow derived stromal cells, and the vitamin C-dependent miRNA regulation in adipose-derived stem cells could potentially differ somewhat from hBMSCs. Similar studies need to be performed on different stem cells originating from other tissue types. Furthermore, we performed our study only at one-time point (six-day) after treatment with vitamin C. It is important to know both the short and long term effects of vitamin C on BMSCs. Future work by our group will focus on validating the predicted miRNA targets and their role in vitamin C-dependent tissue engineering and musculoskeletal development.

Supplementary Materials: The following are available online at www.mdpi.com/2072-6643/10/2/186/s1, Figure S1: Real-time PCR showing no significant changes in miRNA expression in low dose $(25 \mu \mathrm{M}) \mathrm{vitamin} C$ treated samples compared to control (a) miR-4708, (b) miR-29b, (c) miR-3152, and (d) miR-3942 ( $n=4)$, Figure S2: Wordle-based clouds for combine differentially (up and down-regulated) regulated miRNAs of vitamin C treated samples (a) KEGG and (b) GO analysis. Word clouds demonstrating the font size depending on relative word frequencies in KEGG and GO analysis, Table S1: Nucleotide sequences of human primers used for RT-PCR.

Acknowledgments: This publication is supported in part by the National Institutes of Health (NIA-AG036675-06A1, $\mathrm{CI}, \mathrm{WDH}$, and $\mathrm{MWH})$.

Author Contributions: S.F., R.K. and M.W.H. conceived and designed the experiments; S.F., R.K., A.K.M., C.P., S.P.-T. and B.M. performed the experiments; S.F., R.K. and A.K.M. analyzed the data; S.F., W.D.H., M.H., C.M.I. and M.W.H. contributed reagents/materials/analysis tools; S.F. wrote the paper.

Conflicts of Interest: The author declares no conflicts of Interest.

\section{References}

1. Jones, D.L.; Wagers, A.J. No place like home: Anatomy and function of the stem cell niche. Nat. Rev. Mol. Cell Biol. 2008, 9, 11-21. [CrossRef] [PubMed]

2. Li, W.; Wei, S.; Liu, C.; Song, M.; Wu, H.; Yang, Y. Regulation of the osteogenic and adipogenic differentiation of bone marrow-derived stromal cells by extracellular uridine triphosphate: The role of P2Y2 receptor and ERK1/2 signaling. Int. J. Mol. Med. 2016, 37, 63-73. [CrossRef] [PubMed]

3. Xue, J.X.; Gong, Y.Y.; Zhou, G.D.; Liu, W.; Cao, Y.; Zhang, W.J. Chondrogenic differentiation of bone marrow-derived mesenchymal stem cells induced by acellular cartilage sheets. Biomaterials 2012, 33, 5832-5840. [CrossRef] [PubMed]

4. Rahman, F.; Bordignon, B.; Culerrier, R.; Peiretti, F.; Spicuglia, S.; Djabali, M.; Landrier, J.F.; Fontes, M. Ascorbic acid drives the differentiation of mesoderm-derived embryonic stem cells. Involvement of p38 MAPK/CREB and SVCT2 transporter. Mol. Nutr. Food Res. 2017, 61. [CrossRef] [PubMed]

5. Kilberg, M.S.; Terada, N.; Shan, J. Influence of Amino Acid Metabolism on Embryonic Stem Cell Function and Differentiation. Adv. Nutr. 2016, 7, 780S-789S. [CrossRef] [PubMed]

6. Ochocki, J.D.; Simon, M.C. Nutrient-sensing pathways and metabolic regulation in stem cells. J. Cell Biol. 2013, 203, 23-33. [CrossRef] [PubMed]

7. Khillan, J.S. Vitamin A/retinol and maintenance of pluripotency of stem cells. Nutrients 2014, 6, 1209-1222. [CrossRef] [PubMed]

8. Sakayori, N.; Kimura, R.; Osumi, N. Impact of lipid nutrition on neural stem/progenitor cells. Stem Cells Int. 2013, 2013, 973508. [CrossRef] [PubMed]

9. Sangani, R.; Periyasamy-Thandavan, S.; Pathania, R.; Ahmad, S.; Kutiyanawalla, A.; Kolhe, R.; Bhattacharyya, M.H.; Chutkan, N.; Hunter, M.; Hill, W.D.; et al. The crucial role of vitamin C and its transporter (SVCT2) in bone marrow stromal cell autophagy and apoptosis. Stem Cell Res. 2015, 15, 312-321. [CrossRef] [PubMed] 
10. Bae, S.H.; Ryu, H.; Rhee, K.J.; Oh, J.E.; Baik, S.K.; Shim, K.Y.; Kong, J.H.; Hyun, S.Y.; Pack, H.S.; Im, C.; et al. L-Ascorbic acid 2-phosphate and fibroblast growth factor-2 treatment maintains differentiation potential in bone marrow-derived mesenchymal stem cells through expression of hepatocyte growth factor. Growth Factors 2015, 33, 71-78. [CrossRef] [PubMed]

11. Aghajanian, P.; Hall, S.; Wongworawat, M.D.; Mohan, S. The Roles and Mechanisms of Actions of Vitamin C in Bone: New Developments. J. Bone Miner. Res. 2015, 30, 1945-1955. [CrossRef] [PubMed]

12. Fain, O. Musculoskeletal manifestations of scurvy. Joint Bone Spine 2005, 72, 124-128. [CrossRef] [PubMed]

13. Fulzele, S.; Chothe, P.; Sangani, R.; Chutkan, N.; Hamrick, M.; Bhattacharyya, M.; Prasad, P.D.; Zakhary, I.; Bowser, M.; Isales, C.; et al. Sodium-dependent vitamin C transporter SVCT2, expression and function in bone marrow stromal cells and in osteogenesis. Stem Cell Res. 2013, 10, 36-47. [CrossRef] [PubMed]

14. Choi, K.M.; Seo, Y.K.; Yoon, H.H.; Song, K.Y.; Kwon, S.Y.; Lee, H.S.; Park, J.K. Effect of ascorbic acid on bone marrow-derived mesenchymal stem cell proliferation and differentiation. J. Biosci. Bioeng. 2008, 105, 586-594. [CrossRef] [PubMed]

15. Potdar, P.D.; D'Souza, S.B. Ascorbic acid induces in vitro proliferation of human subcutaneous adipose tissue derived mesenchymal stem cells with upregulation of embryonic stem cell pluripotency markers Oct 4 and SOX2. Hum. Cell 2010, 23, 152-155. [CrossRef] [PubMed]

16. Naidu, K.A. Vitamin C in human health and disease is still a mystery? An overview. Nutr. J. $2003,2,7$. [CrossRef] [PubMed]

17. Drouin, G.; Godin, J.R.; Pagé, B. The genetics of vitamin C loss in vertebrates. Curr. Genomics 2011, 12, 371-378. [CrossRef] [PubMed]

18. Nishikimi, M.; Yagi, K. Molecular basis for the deficiency in humans of gulonolactone oxidase, a key enzyme for ascorbic acid biosynthesis. Am. J. Clin. Nutr. 1991, 54 (Suppl. 6), 1203S-1208S. [CrossRef] [PubMed]

19. Chung, T.L.; Brena, R.M.; Kolle, G.; Grimmond, S.M.; Berman, B.P.; Laird, P.W.; Pera, M.F.; Wolvetang, E.J. Vitamin C promotes widespread yet specific DNA demethylation of the epigenome in human embryonic stem cells. Stem Cells 2010, 28, 1848-1855. [CrossRef] [PubMed]

20. Blaschke, K.; Ebata, K.T.; Karimi, M.M.; Zepeda-Martínez, J.A.; Goyal, P.; Mahapatra, S.; Tam, A.; Laird, D.J.; Hirst, M.; Rao, A.; et al. Vitamin C induces Tet-dependent DNA demethylation and a blastocyst-like state in ES cells. Nature 2013, 500, 222-226. [CrossRef] [PubMed]

21. Poal-Manresa, J.; Little, K.; Trueta, J. Some observations on the effects of vitamin C deficiency on bone. Br. J. Exp. Pathol. 1970, 51, 372-378. [PubMed]

22. Kipp, D.E.; McElvain, M.; Kimmel, D.B.; Akhter, M.P.; Robinson, R.G.; Lukert, B.P. Scurvy results in decreased collagen synthesis and bone density in the guinea pig animal model. Bone 1996, 18, 281-288. [CrossRef]

23. Chen, J.; Guo, L.; Zhang, L.; Wu, H.; Yang, J.; Liu, H.; Wang, X.; Hu, X.; Gu, T.; Zhou, Z.; et al. Vitamin C modulates TET1 function during somatic cell reprogramming. Nat. Genet. 2013, 45, 1504-1509. [CrossRef] [PubMed]

24. Ivanyuk, D.; Budash, G.; Zheng, Y.; Gaspar, J.A.; Chaudhari, U.; Fatima, A.; Bahmanpour, S.; Grin, V.K.; Popandopulo, A.G.; Sachinidis, A.; et al. Ascorbic Acid-Induced Cardiac Differentiation of Murine Pluripotent Stem Cells: Transcriptional Profiling and Effect of a Small Molecule Synergist of Wnt/ $\beta$-Catenin Signaling Pathway. Cell. Physiol. Biochem. 2015, 36, 810-830. [CrossRef] [PubMed]

25. Weinhold, B. Epigenetics: The science of change. Environ. Health Perspect. 2006, 114, A160-A167. [CrossRef] [PubMed]

26. Fu, G.; Ren, A.; Qiu, Y.; Zhang, Y. Epigenetic Regulation of Osteogenic Differentiation of Mesenchymal Stem Cells. Curr. Stem Cell Res. Ther. 2016, 11, 235-246. [CrossRef] [PubMed]

27. Yannarelli, G.; Pacienza, N.; Cuniberti, L.; Medin, J.; Davies, J.; Keating, A. Brief report: The potential role of epigenetics on multipotent cell differentiation capacity of mesenchymal stromal cells. Stem Cells 2013, 31, 215-220. [CrossRef] [PubMed]

28. Challen, G.A.; Sun, D.; Jeong, M.; Luo, M.; Jelinek, J.; Berg, J.S.; Bock, C.; Vasanthakumar, A.; Gu, H.; Xi, Y.; et al. Dnmt3a is essential for hematopoietic stem cell differentiation. Nat. Genet. 2011, 44, $23-31$. [CrossRef] [PubMed]

29. Arnsdorf, E.J.; Tummala, P.; Castillo, A.B.; Zhang, F.; Jacobs, C.R. The epigenetic mechanism of mechanically induced osteogenic differentiation. J. Biomech. 2010, 43, 2881-2886. [CrossRef] [PubMed] 
30. Alexanian, A.R. Epigenetic modifiers promote efficient generation of neural-like cells from bone marrowderived mesenchymal cells grown in neural environment. J. Cell. Biochem. 2007, 100, 362-371. [CrossRef] [PubMed]

31. Sangani, R.; Periyasamy-Thandavan, S.; Kolhe, R.; Bhattacharyya, M.H.; Chutkan, N.; Hunter, M.; Isales, C.; Hamrick, M.; Hill, W.D.; Fulzele, S. MicroRNAs-141 and 200a regulate the SVCT2 transporter in bone marrow stromal cells. Mol. Cell. Endocrinol. 2015, 410, 19-26. [CrossRef] [PubMed]

32. Ebata, K.T.; Mesh, K.; Liu, S.; Bilenky, M.; Fekete, A.; Acker, M.G.; Hirst, M.; Garcia, B.A.; Ramalho-Santos, M. Vitamin $\mathrm{C}$ induces specific demethylation of $\mathrm{H} 3 \mathrm{~K} 9 \mathrm{me} 2$ in mouse embryonic stem cells via $\mathrm{Kdm} 3 \mathrm{a} / \mathrm{b}$. Epigenet. Chromatin 2017, 10, 36. [CrossRef] [PubMed]

33. Abbey, D.; Seshagiri, P.B. Ascorbic acid-mediated enhanced cardiomyocytes differentiation of mouse ES-cells involves interplay of DNA methylation and multiple-signals. Differentiation 2017, 96, 1-14. [CrossRef] [PubMed]

34. Eid, W.; Abdel-Rehim, W. Vitamin C promotes pluripotency of human induced pluripotent stem cells via the histone demethylase JARID1A. Biol. Chem. 2016, 397, 1205-1213. [CrossRef] [PubMed]

35. Camarena, V.; Wang, G. The epigenetic role of vitamin C in health and disease. Cell. Mol. Life Sci. 2016, 73, 1645-1658. [CrossRef] [PubMed]

36. Young, J.I.; Züchner, S.; Wang, G. Regulation of the Epigenome by Vitamin C. Annu. Rev. Nutr. 2015, 35, 545-564. [CrossRef] [PubMed]

37. Yin, R.; Mao, S.Q.; Zhao, B.; Chong, Z.; Yang, Y.; Zhao, C.; Zhang, D.; Huang, H.; Gao, J.; Li, Z.; et al. Ascorbic acid enhances Tet-mediated 5-methylcytosine oxidation and promotes DNA demethylation in mammals. J. Am. Chem. Soc. 2013, 135, 10396-10403. [CrossRef] [PubMed]

38. Nicolas, F.E.; Lopez-Martinez, A.F. MicroRNAs in human diseases. Recent Pat. DNA Gene Seq. 2010, 4, 142-154. [CrossRef] [PubMed]

39. He, L.; Hannon, G.J. MicroRNAs: Small RNAs with a big role in gene regulation. Nat. Rev. Genet. 2004, 5, 522-531. [CrossRef] [PubMed]

40. Cruz-Santos, M.C.; Aragón-Raygoza, A.; Espinal-Centeno, A.; Arteaga-Vázquez, M.; Cruz-Hernández, A.; Bako, L.; Cruz-Ramírez, A. The Role of microRNAs in Animal Cell Reprogramming. Stem Cells Dev. 2016, 25, 1035-1049. [CrossRef] [PubMed]

41. Mathieu, J.; Ruohola-Baker, H. Regulation of stem cell populations by microRNAs. Adv. Exp. Med. Biol. 2013, 786, 329-351. [PubMed]

42. Luo, W.; Nie, Q.; Zhang, X. MicroRNAs involved in skeletal muscle differentiation. J. Genet. Genomics 2013, 40,107-116. [CrossRef] [PubMed]

43. Yi, R.; Fuchs, E. MicroRNAs and their roles in mammalian stem cells. J. Cell Sci. 2011, 124, $1775-1783$. [CrossRef] [PubMed]

44. Calabrese, G.; Giuffrida, R.; Lo Furno, D.; Parrinello, N.L.; Forte, S.; Gulino, R.; Colarossi, C.; Schinocca, L.R.; Giuffrida, R.; Cardile, V.; et al. Potential Effect of CD271 on Human Mesenchymal Stromal Cell Proliferation and Differentiation. Int. J. Mol. Sci. 2015, 16, 15609-15624. [CrossRef] [PubMed]

45. Cuthbert, R.J.; Giannoudis, P.V.; Wang, X.N.; Nicholson, L.; Pawson, D.; Lubenko, A.; Tan, H.B.; Dickinson, A.; McGonagle, D.; Jones, E. Examining the feasibility of clinical grade CD271 + enrichment of mesenchymal stromal cells for bone regeneration. PLoS ONE 2015, 10, e0117855. [CrossRef] [PubMed]

46. Kolhe, R.; Hunter, M.; Liu, S.; Jadeja, R.N.; Pundkar, C.; Mondal, A.K.; Mendhe, B.; Drewry, M.; Rojiani, M.V.; Liu, Y.; et al. Gender-specific differential expression of exosomal miRNA in synovial fluid of patients with osteoarthritis. Sci. Rep. 2017, 7, 2029. [CrossRef] [PubMed]

47. Tuan, R.S.; Boland, G.; Tuli, R. Adult mesenchymal stem cells and cell-based tissue engineering. Arthritis Res. Ther. 2003, 5, 32-45. [CrossRef] [PubMed]

48. Tang, X.L.; Xu, M.J.; Li, Z.H.; Pan, Q.; Fu, J.H. Effects of vitamin E on expressions of eight microRNAs in the liver of Nile tilapia (Oreochromis niloticus). Fish Shellfish Immunol. 2013, 34, 1470-1475. [CrossRef] [PubMed]

49. Gaedicke, S.; Zhang, X.; Schmelzer, C.; Lou, Y.; Doering, F.; Frank, J.; Rimbach, G. Vitamin E dependent microRNA regulation in rat liver. FEBS Lett. 2008, 582, 3542-3546. [CrossRef] [PubMed]

50. Merrigan, S.L.; Kennedy, B.N. Vitamin D receptor agonists regulate ocular developmental angiogenesis and modulate expression of dre-miR-21 and VEGF. Br. J. Pharmacol. 2017, 174, 2636-2651. [CrossRef] [PubMed]

51. Arboleda, J.F.; Urcuqui-Inchima, S. Vitamin D-Regulated MicroRNAs: Are They Protective Factors against Dengue Virus Infection? Adv. Virol. 2016, 2016, 1016840. [CrossRef] [PubMed] 
52. Drummond, M.J.; Glynn, E.L.; Fry, C.S.; Dhanani, S.; Volpi, E.; Rasmussen, B.B. Essential amino acids increase microRNA-499, $-208 \mathrm{~b}$, and $-23 \mathrm{a}$ and downregulate myostatin and myocyte enhancer factor 2C mRNA expression in human skeletal muscle. J. Nutr. 2009, 139, 2279-2284. [CrossRef] [PubMed]

53. Kim, S.M.; Lim, S.M.; Yoo, J.A.; Woo, M.J.; Cho, K.H. Consumption of high-dose vitamin C (1250 mg per day) enhances functional and structural properties of serum lipoprotein to improve anti-oxidant, anti-atherosclerotic, and anti-aging effects via regulation of anti-inflammatory microRNA. Food Funct. 2015, 6, 3604-3612. [CrossRef] [PubMed]

54. Gao, Y.; Han, Z.; Li, Q.; Wu, Y.; Shi, X.; Ai, Z.; Du, J.; Li, W.; Guo, Z.; Zhang, Y. Vitamin C induces a pluripotent state in mouse embryonic stem cells by modulating microRNA expression. FEBS J. 2015, 282, 685-699. [CrossRef] [PubMed]

55. Kim, Y.J.; Ku, S.Y.; Rosenwaks, Z.; Liu, H.C.; Chi, S.W.; Kang, J.S.; Lee, W.J.; Jung, K.C.; Kim, S.H.; Choi, Y.M.; et al. MicroRNA expression profiles are altered by gonadotropins and vitamin $\mathrm{C}$ status during in vitro follicular growth. Reprod. Sci. 2010, 17, 1081-1089. [PubMed]

56. Di Fiore, R.; Drago-Ferrante, R.; Pentimalli, F.; Di Marzo, D.; Forte, I.M.; D’Anneo, A.; Carlisi, D.; De Blasio, A.; Giuliano, M.; Tesoriere, G.; et al. MicroRNA-29b-1 impairs in vitro cell proliferation, self-renewal and chemoresistance of human osteosarcoma 3AB-OS cancer stem cells. Int. J. Oncol. 2014, 45, 2013-2023. [CrossRef] [PubMed]

57. Zhang, X.; Jiang, P.; Shuai, L.; Chen, K.; Li, Z.; Zhang, Y.; Jiang, Y.; Li, X. miR-589-5p inhibits MAP3K8 and suppresses CD90(+) cancer stem cells in hepatocellular carcinoma. J. Exp. Clin. Cancer Res. 2016, 35, 176. [CrossRef] [PubMed]

58. Quan, Y.; Wang, Z.; Gong, L.; Peng, X.; Richard, M.A.; Zhang, J.; Fornage, M.; Alcorn, J.L.; Wang, D. Exosome miR-371b-5p promotes proliferation of lung alveolar progenitor type II cells by using PTEN to orchestrate the PI3K/Akt signaling. Stem Cell Res. Ther. 2017, 8, 138. [CrossRef] [PubMed]

59. Su, R.; Lin, H.S.; Zhang, X.H.; Yin, X.L.; Ning, H.M.; Liu, B.; Zhai, P.F.; Gong, J.N.; Shen, C.; Song, L.; et al. MiR-181 family: Regulators of myeloid differentiation and acute myeloid leukemia as well as potential therapeutic targets. Oncogene 2015, 34, 3226-3239. [CrossRef] [PubMed]

60. Jones, M.F.; Hara, T.; Francis, P.; Li, X.L.; Bilke, S.; Zhu, Y.; Pineda, M.; Subramanian, M.; Bodmer, W.F.; Lal, A. The CDX1-microRNA-215 axis regulates colorectal cancer stem cell differentiation. Proc. Natl. Acad. Sci. USA 2015, 112, E1550-E1558. [CrossRef] [PubMed]

61. Pustylnik, S.; Fiorino, C.; Nabavi, N.; Zappitelli, T.; da Silva, R.; Aubin, J.E.; Harrison, R.E. EB1 levels are elevated in ascorbic Acid (AA)-stimulated osteoblasts and mediate cell-cell adhesion-induced osteoblast differentiation. J. Biol. Chem. 2013, 288, 22096-22110. [CrossRef] [PubMed]

62. Jubiz, W.; Ramirez, M. Effect of vitamin C on the absorption of levothyroxine in patients with hypothyroidism and gastritis. J. Clin. Endocrinol. Metab. 2014, 99, E1031-E1034. [CrossRef] [PubMed]

63. Williams, G.R.; Bassett, J.H.D. Thyroid diseases and bone health. J. Endocrinol. Investig. 2017, 2, 3-13. [CrossRef] [PubMed]

64. Williams, G.R. Thyroid hormone actions in cartilage and bone. Eur. Thyroid. J. 2013, 2, 3-13. [CrossRef] [PubMed]

65. Bayerle-Eder, M.; Pleiner, J.; Mittermayer, F.; Schaller, G.; Roden, M.; Waldhäusl, W.; Bieglmayer, C.; Wolzt, M. Effect of systemic vitamin C on free fatty acid-induced lipid peroxidation. Diabetes Metab. 2004, 30, 433-439. [CrossRef]

66. Ginter, E.; Ondreicka, R.; Bobek, P.; Simko, V. The influence of chronic vitamin C deficiency on fatty acid composition of blood serum, liver triglycerides and cholesterol esters in guinea pigs. J. Nutr. 1969, 99, 261-266. [CrossRef] [PubMed]

67. Rashid, M.A.; Haque, M.; Akbar, M. Role of Polyunsaturated Fatty Acids and Their Metabolites on Stem Cell Proliferation and Differentiation. Adv. Neurobiol. 2016, 12, 367-380. [PubMed]

68. Das, U.N. Influence of polyunsaturated fatty acids and their metabolites on stem cell biology. Nutrition 2011, 27, 21-25. [CrossRef] [PubMed]

(C) 2018 by the authors. Licensee MDPI, Basel, Switzerland. This article is an open access article distributed under the terms and conditions of the Creative Commons Attribution (CC BY) license (http:/ / creativecommons.org/licenses/by/4.0/). 